\title{
Identity Salience and Its Dynamics in Palestinians Adolescents
}

\author{
Ibrahim A. Kira ${ }^{1}$, Abdul Wahhab Nasser Alawneh ${ }^{2}$, Sharifa Aboumediane ${ }^{1}$, \\ Jamal Mohanesh ${ }^{3}$, Bulent Ozkan ${ }^{4}$, Hala Alamia ${ }^{1}$ \\ ${ }^{1}$ Center of Cumulative Trauma Studies, Stone Mountain, USA; \\ ${ }^{2}$ Arab and Middle East Resource Center, Dearborn, USA; \\ ${ }^{3}$ ACCESS Community Health and Research Center, Dearborn, USA; \\ ${ }^{4}$ Wayne State University, Detroit, USA. \\ Email: kiraaref@aol.com \\ Received May $8^{\text {th }}, 2011$; revised August $29^{\text {th }}, 2011$; accepted October $2^{\text {nd }}, 2011$.
}

\begin{abstract}
The goal is to build and test a measure for identity salience and use it to explore the validity of some assumptions of the identity trauma theory (ITT). ITT suggests that the salience of identity concerns, personal, and collective enhances or negatively affect agency and self-efficacy and explain suicidality and militancy. Using samples of 880 Palestinian adolescents, we developed in the first study a measure for identity salience that included sub-scales for identity commitment and militancy. In the second study we used the measure along with measures for fear of death, mental health variables, and trauma types. Personal identity traumas were associated with decrease in fear of death; increase in mental health problems and in clinical suicide. Collective identity traumas were associated with increase in identity commitment and militancy. Militancy was found to be associated with decreased PTSD which suggests that militancy acts as anxiety buffer. Identity commitment was associated with decrease in militancy. The implications of the results were discussed.
\end{abstract}

Keywords: Identity Salience, Mortality Salience, Suicidality, Militancy, Identity Trauma Theory

\section{Introduction}

Identity develops through life from attachment to parents (Bowlby, 1969, 1988) to autonomy and independence to the stage of interdependence and being part of the networks of the society. An impressive body of research focused on the early development and related attachment dynamics. Individuation and identity development did not attract, so far, an equal attention of research. Identity development of the individual is connected to the individuation process in early adolescence and adulthood (e.g., Erikson, 1963; Gross, 1987; Rasmussen, \& Erikson, 1964). In adolescence and early adulthood. The individual develops, at this stage, increased self awareness and increasingly complex identity to grow with him over his/her life span. The acquired identity, at this stage of development, became central to personal and interpersonal dynamics. According to developmental theories, self-definition that determines identity comprises of, at least, two fundamental self-representations or self-schemata: Personal self representations and social or group self representations that connect the individual to his status in the global interdependent network. The second is derived from membership in larger, more impersonal collectives or social categories (e.g. Tajfel, \& Turner, 1986). Based on this developmental framework, (ITT) differentiates between at least two different kinds of identity traumas that can challenge the existence of either: personal identity Trauma (PIT) (e.g., violation of self autonomy by rape, sexual or physical abuse, and involve fears of loss of autonomy and independent identity that the individual develops), and collective or social identity trauma (CIT) (e.g., targeted genocide, holocaust, slavery, discrimination, and different kinds of social structural violence that may triggers fears of the group subjugation or annihilation), (e.g., Kira, 2001; Kira, 2010, Kira et al., 2008). CIT that may overwhelm individuals can be socio-political, historical or social structural traumas (SST). SSTs are those traumas associated with perceived relative deprivation and/or social structural violence. Examples of social structural violence are extreme poverty (e.g., Cassiman, 2005, Smith, Spears, \& Hamstra, 1999; Walker, \& Pettigrew, 1984), and extreme gender discrimination. (e.g., Kira et al., 2010)

PITs and CITs are main causal factors for identity terror and fear of losing the developmentally acquired identities. Each identity trauma type may challenge the respective identity sheer existence, causing identity annihilation terror, and may negatively affects physical and mental health as well as related personal, social and political dynamics. Further, collective Identity is increasingly conceptualized as fundamental to the maintenance and reproduction of political conflict (Kira, 2002, 2006).

According to this theory, self-efficacy feelings, as contrasted to self-esteem, buffer against fear of loss of identities that the individual develops across life (Bandura, 1997). Acquired identities are nested in hierarchical dynamic structure. Identity nested hierarchy is a dynamic coherent whole, that is derived by a governing self-agency that is associated with feelings of self-efficacy and/or collective agency and control beliefs (cf, e.g., Bandura, 1997, Kira, 2002, 2006, 2010).

Identity traumas, within this development-based trauma frame work, are contrasted to other trauma types, for example, attachment traumas (e.g., abandonment by mother of her infant) that involve fears of security loss that negatively activates security salience, and survival traumas (e.g., attacks by weapons, or natural disasters) and involve fears of death that triggers mortality salience (Kira et al., 2008, Kira, 2010). On the other hand, identity traumas can cause fears and terror of identity loss/ identity annihilation or subjugation and/or return to the state of dependency, threatening the salience of personal or collective identity.

Identity salience or dormancy refers to the status of one identity in the hierarchy of nested identities, whether it is central, or peripheral. Individuals process stimuli according to their as- 
signed negative or positive value as relevant and important and their potential threat to their salient identities (Kira, 1987, 1997). More salient, relevant, super-ordinate, or central identities are more likely to be activated and act as lens through which individuals appraise and process relevant situational information. Identities higher in the salience/dormancy hierarchy will take precedence over identities lower in the salience/ dormancy hierarchy and will direct/bias individual perceptions, emotions and actions and establish situational priorities. (c.f., e.g., Stryker, \& Burke, 2000, Stryker, \& Serpe, 1982, McCall, \& Simmons, 1978; Ashmore, Deaux, \& McLaughlin-Volpe., 2004; Kira, 2010).

Nested identities hierarchy is mostly dynamic and is modifiable by different types of identity traumatic events. Serious threats to one's dormant identity can move it to be more salient and rearrange the centrality and salience of identities in the dynamic nested identities' hierarchy. Realigning the nested identity hierarchy can be ongoing process. Several assumptions were deduced from trauma identity theory framework:

1) Collective identity traumas, (e.g., the holocaust, September 11, or Pearl Harbor attack) kindle this national or group collective identity to be more salient and push personal or physical identity to be more dormant decreasing fear of physical death, and increasing fear of group or collective annihilation/ extinction or subjugation. The opposite will happen if the event is related to personal identity, for example rape attack or domestic violence, which may rearrange the salience hierarchy.

2) Collective identity, when became salient, increases the level of commitment, for example ethnic group solidarity, and militancy to protect such identity (cf., e.g., Ibn Khaldûn, 1968). Identities with higher levels of commitment and militancy will take precedence over those with lower levels of commitment and/or militancy, when action is called for.

3) Identity traumas, personal, and collective, activate different type of primal fears that deactivate fear of death. When personal identity is seriously threatened, self-annihilation panic can erupt and deactivate the salience of collective identity as well as individual's mortality and may trigger suicidal thoughts and actions. Conversely, serious collective identity threats, for example in a struggle against domination or oppression, can activate collective annihilation, sub-ordination or subjugation fears and deactivate personal identity concerns as well as mortality salience and may trigger militancy and/or extremism. In each case, mortality concerns become dormant.

4) Persons who reach such level of militancy to one's own salient identity may be ready to ignore or even sacrifice the existence of other less salient identities. An example is committing suicide (eliminating the physical entity); to regain personal autonomy and control that they perceive they lost by rape, incest or betrayal. Another example is the readiness to die for the country in a war to promote or achieve the collective national identity goals (Kira, 2002, 2006).

\section{The Goals of the First Study}

The goal of the first study is to develop a measure for collective identity commitment and militancy (identity salience) and explore its reliability, and test its construct validity. We will test its predictive validity through testing basic predictions of trauma developmental theory in the second study. Testing the measure on samples of Palestinian adolescents may allow us to further test some of assumptions of this theory in adolescents that are subjected to high collective identity trauma load and are developing highly politicized collective identity.

\section{The First Study}

\section{Hypotheses}

Hypothesis 1: Identity salience scale (ISS) developed in this study has adequate reliability.

Hypothesis 2: ISS has adequate construct validity in the population under study.

\section{The First Study: Method}

\section{Participants}

Participants were 880 adolescents, high school students from Gaza and West Bank in Palestine (438 from West bank, and 442 from Gaza). While we used Gaza data to conduct confirmatory factor analysis of identity salience scale, the focus of this paper will be on West Bank participants $(\mathrm{N}=438)$.

Family size seemed to be higher in Gaza compare to West Bank samples.

West Bank participants included 54.6\% males, and 45.4\% females. Age ranged from 12 - 19, mean age was 15.66, SD of 1.43. Family size ranged from 2 - 22 with mean of 7.99 , SD 2.69. $40 \%$ of the participants were from middle school and $60 \%$ from high school.

Gaza's Participants included 442 adolescents, 47.5\% males and $52.5 \%$ females. Participants included 5\% from villages' residents, $50.3 \%$ from Gaza city residents, and $44.7 \%$ from refugee camps' residents. Age ranged between 11 and 19, with mean of 15.89 and SD of 2.86. Family size average was 9.77 and SD of 2.79. Family size seemed to be higher in Gaza compare to West Bank samples. In the sample $99 \%$ are Muslims and $1 \%$ is Christians.

\section{Procedure}

A focus group discussion of five professionals developed a pool of fifty items that focus on person's group identity commitment and militancy according to the theory. The fifty items scale tested in small convenient sample of 30 Arab refugee adolescents in USA. Based on item analysis and the least number of items criteria, research team chose 10 items that represent the concept of identity salience. Research team decided to make the items non-specific to a group, we added other questions that ask about which groups of belonging are more important and relevant at the time as separate probe questions.

The study was approved by Palestinian Authority. Participants were recruited through West Bank and Gaza School systems and covered 7 schools in each region. The seven schools were randomly selected and included schools from refugee camps. Participation was completely voluntary and fully informed. Research participants told that they may withdraw from the study at any time. Parents were informed of the nature of the research that target understanding the effects of different traumas on their children health and mental health; active informed parental consent and written adolescents' ascent were obtained or offered by participating schools and research team. Some parents approved verbally but chose not to sign due the political situation at the time or for other reasons. No identifying information was recorded that can link the subjects to the data. The disclosure of the data could not reasonably place the subjects at any risk or any liability according to federal and local human subjects' guidelines. Interviews were conducted face-to-face in Arabic by trained Palestinian teachers and local research team and took between 45 - 60 minutes as it included 
other measures than those utilized in this presentation.

The participation was $75 \%$ from randomly chosen classes within the seven schools. The field work was conducted from January to March 2005 in West Bank and from April to June 2005 in Gaza. The final version of the measure was tested in Gaza and West Bank participants separately.

\section{Analysis}

Scale alpha analysis was conducted to check the reliability of the measure. Test re-test was conducted on small sample $(\mathrm{n}=$ 30). Exploratory factor analysis was conducted on West Bank sub-sample $(n=438)$ and confirmatory factor analysis was conducted on Gaza sub-sample to test the construct validity of Identity salience scale (ISS) and its sub-scales on different subsamples. SPSS statistical package data analysis software was used to conduct all the statistical analyses.

\section{The First Study: Results}

\section{Construct Validity}

Exploratory principal components factor analysis was conducted on the West Bank sub-sample $(n=438)$ using Eigen value of 1.00 as criteria for extraction and with orthogonal rotations. The analysis yielded two factors that represent the two sub-scales. The two factors accounted for $51.65 \%$ of the variance. Table 1 represented the two orthogonally rotated factors.

Confirmatory factor analysis, conducted on a different set of data that is comparable to West Bank data (Gaza data, $\mathrm{N}=442$ ), confirmed the factor structure of the measure. The two factor model of identity salience: Identity commitment, and identity militancy has an adequate fit (Chi-square $=70.106, \mathrm{df}=32, \mathrm{P}$ $=.000, \mathrm{CFI}=.952$, RMSEA $=.052)$. The scale with its two sub-scales has good construct validity. Figure 1 illustrates this model.

\section{Reliability}

The Identity salience measure developed in this study found to have alpha of .80 , with alpha of .74 for commitment, .75 for militancy sub-scales. Test-re-test reliability after three weeks was .76.

\section{Descriptive Results}

The mean score for identity salience in the sample was Mean $=58.29$ and $\mathrm{SD}=13.71$ (range $13-90)$. Females $(\mathrm{N}=197)$, have significantly higher scores than males $(\mathrm{N}=237)$, (females Mean $=60.90, \mathrm{SD}=12.66$, males Mean $=56.32, \mathrm{SD}=14.13, p$
$<.000)$. Females have significantly higher scores in identity commitment than males (females $\mathrm{M}=27.65, \mathrm{SD}=6.92$, males $\mathrm{M}=26.27, \mathrm{SD}=7.77, p<.05)$, however there are no differences in their level of militancy (females $\mathrm{M}=19.89 \mathrm{SD}=5.01$, males $\mathrm{M}=19.89, \mathrm{SD}=5.09$ ).

\section{Conclusion}

The ISS developed in the current study, and its two subscales have adequate reliability and construct validity.

\section{The Second Study}

The goal of second study was to use the constructed identity measure to check some of the trauma developmental theory assumptions and check its predictive validity.

\section{Hypotheses}

Hypothesis 1: Self-efficacy, autonomous functioning and agency is at the core of identity commitment and militancy.

Hypothesis 2: Personal identity traumas and negative appraisal of traumas will predict identity commitment, while collective identity traumas and positive appraisal of traumas predict increase in militancy.

Hypothesis 3: Identity traumas, personal and collective predict reduced fear of death, and increased annihilation anxiety (AA).

Hypothesis 4: Annihilation anxiety, militancy and trauma variables predict suicidality:

Hypothesis 5: Identity salience, annihilation anxiety (AA), as well as fear of death mediates the effects of identity traumas on suicidality, mental health variables, and militancy.

\section{The Second Study: Method}

\section{Participants}

The study used West Bank sub-sample ( $\mathrm{N}=438)$ according to the procedures described in the first study. Using short measures approach help to limit the interview time to be manageable to overcome the fatigue effects, to ensure the authenticity and reliability of responses.

\section{Measures}

All measures used in the study, except fear of death measure, were previously constructed in English. They subsequently translated into Arabic by three bilingual mental health professsionals who each individually translated the measures and then

Table 1.

Rotated component matrix for identity salience measure.

\begin{tabular}{|c|c|c|}
\hline Items/Factors & 1 & 2 \\
\hline Fear 26: I think a lot about the destiny of my group to which I belong. & .174 & .183 \\
\hline Fear 22: I feel personally threatened because of criminal acts committed against me or my group. & .710 & -.165 \\
\hline Fear 21: Sometimes I wish to die or to kill somebody before some one from my group get hurt or die (by other groups). & .619 & .199 \\
\hline Fear 23: When my religion or my ethnic or cultural or national group gets threatened, their importance comes before the importance of my family. & .571 & .341 \\
\hline Fear 24: When my religion or my ethnic or cultural or national group gets threatened, their importance comes before the importance of me. & .538 & .421 \\
\hline Fear 25: The idea that I cannot help my group bothers me a lot. & .535 & .389 \\
\hline Fear 19: The threat to my group made me stronger and more able to defend my group. & .128 & .836 \\
\hline Fear 20: The threat to my group made me stronger and more able to defend myself. & .164 & .772 \\
\hline Fear 17: I am ready to die for the honor of my group I belong to. & .112 & 639 \\
\hline Fear 16: I do not care of death when I have to defend my ethnic, national or religious group. & .360 & .382 \\
\hline
\end{tabular}




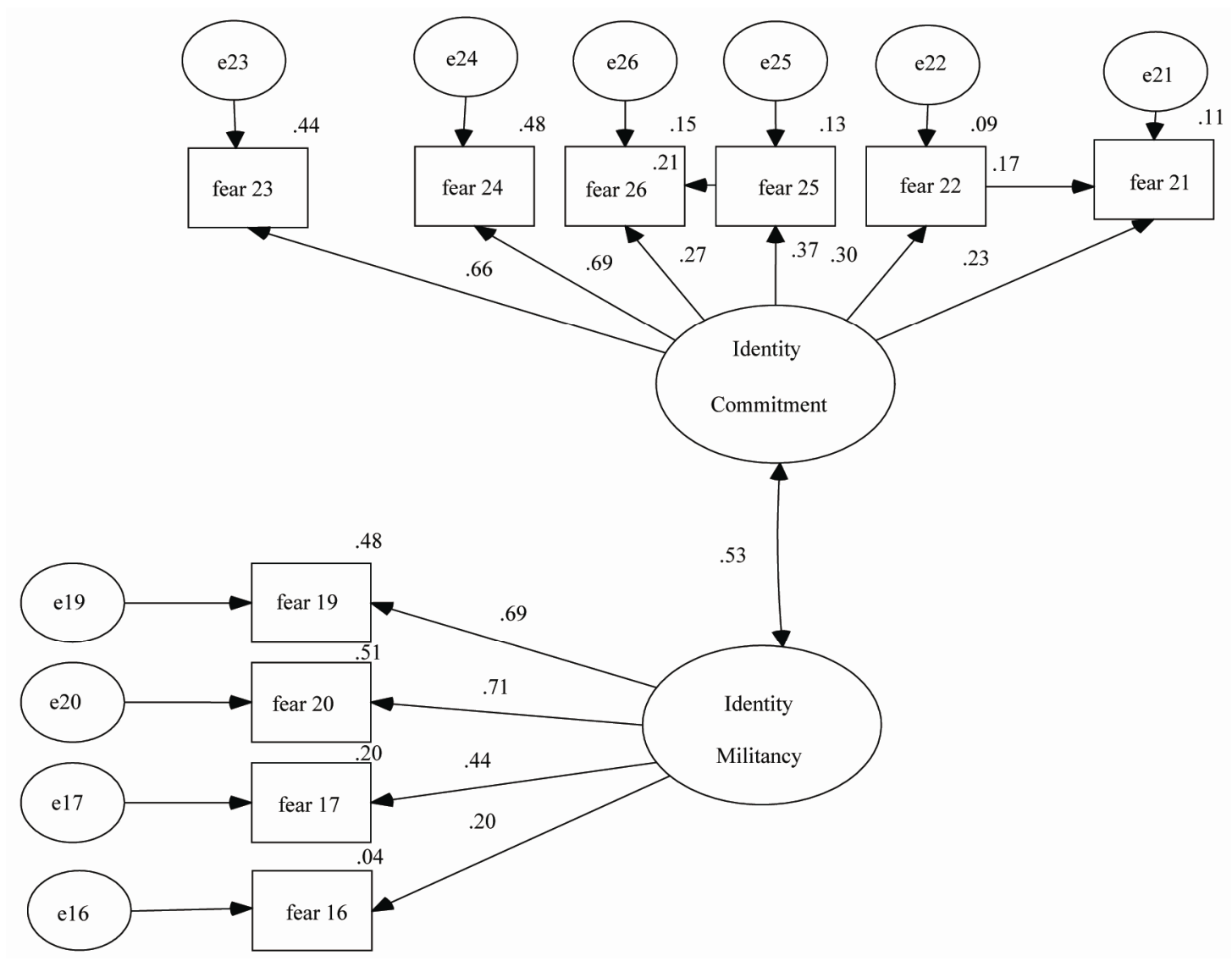

Figure 1.

Confirmatory factor analysis of identity salience scale: the two-factor model (Gaza data).

met together to establish a consensus on the final version based on the criteria of adequate cultural sensitivity and appropriateness in measuring the construct of the instrument.. A fourth mental health professional did the reverse translation. These measures were pilot tested in focus groups.

\section{Independent Variables Measures}

\section{Cumulative Trauma Scale and Its Sub-Scales}

The measure includes 61 items. Each item describes extremely stressful event. The participant was asked to report if he/she experienced it or not, how many times he have experienced the event, at what age first time, and how much it affected him positively or negatively on a scale from 0 to 7 . The measure provides us with general scales for two of cumulative Trauma doses: Occurrence and frequency of happenings, two appraisal sub-scales: negative and positive appraisal. It includes, at this level, four sub-scales for each trauma type. Trauma types include according to Kira's taxonomy of trauma (Kira, 2001, 2004, Kira et al., 2008, 2011): Collective identity, personal identity, attachment, interdependence, physical survival, and self-actualization. The measure proved to have good reliability and validity in previous two studies, one on clinical adult population $(n=399)$ and the other on adolescent Iraqi refugees and African Americans $(n=390)$ in US. For the purpose of this study we focused on cumulative trauma, personal identity, and collective identity traumas occurrence and their negative appraisal. The cumulative trauma dose scale has alpha reliability of .88 in the current study. Trauma type's sub-scales have adequate alphas that ranged from .68 to .90 .

\section{Potential Mediating and/or Moderating Variables}

Identity Salience scale developed in the first study. The answer of scale questions is based on 7-point Likert type scale with 1 means completely disagrees and 7 absolutely agree. High scores on the scale means higher group identity salience and low scores means more personal identity salience. Based on factor analysis, the measure has two sub-scales:

Identity commitment sub-scale: The measure is a 6-item scale and measures the degree of commitment to the individual national or ethnic group. It asks questions like "When my group is threatened its interest come first before mine".

Identity militancy sub-scale: The sub-scale has 4 items. It includes questions like "I am ready to die for the honor of my group to which I belong to"

Fear of death and dying measure (12-item measure): The measure was previously developed and tested in Hebrew and Arabic languages in Israel. Fear of death and dying was measured by 12 items, such as "I am afraid of death" and "The thought of being unable to do things for myself at the end of life troubles me very much." (Carmel, \& Mutran (1997a). Each item was measured by a five-point scale ranging from $1=$ completely disagree to $5=$ completely agree. According to the results reported by Carmel and Mutran (1997b) and Wemer and Carmel (2001b), two indices, one for fear of dying and one for fear of death, were found. Both factors had an adequate internal validity: Cronbach's alpha $=.80$ for the six items in the fear of death factor and Cronbach's alpha $=.81$ for the six items of the fear of dying factor. The final score for each factor is the average of the answers to the relevant items. The higher the score, 
the greater is the participant's fear of death or/and dying. In our study we find the same two factors, however, to accurately describe what the scale is measuring we decided to re-label the fear of dying as fear of loss of functioning and independence in old age, while the first scale accurately describe the fear of actual death. It has alpha of .80 in current study.

\section{Dependent Variable Measures}

Annihilation anxiety measure: The measure is based on the assumption that there are two main sources of the emergence of annihilation anxiety, personal identity and collective identity survival threats (traumas). The 3-item scale have been used before on Iraqi refugees in Michigan and found to have good reliability (alpha. 93), divergent and predictive validity (Templin, Kira et al., 2006). It has an alpha of .87 in the current study.

PTSD Measure (CAPS-2) (18 items): This measure was developed by Blacke and his colleagues (Blacke et. al., 1990). It is widely used to assess PTSD. It is a structured clinical interview that assesses 17 symptoms rated on frequency and severity on a 5 -point scale. CAPS demonstrated high reliability with a range from $0.92-0.99$ and showed good convergent and discriminant validity (Weathers, Keane, \& Davidson, 2001). In this study, we used the frequency sub-scale of CAPS-2 that is currently widely used in psychiatric literature. It has alpha of .91 in the current study.

CES-D Depression Measure: Center for Epidemiologic studies-Depression mood scale is a 20 item scale (Radloff, 1977). Each item is assessed on a 4-point scale and reflects the frequency that each symptom is experienced $(0=$ none of the time, $3=$ all of the time). Adequate reliability and validity have been reported for the CES-D (Orme, Reis, \& Herz, 1986). A cutoff score of $\geq 16$ is commonly used for the CES-D to indicate a need for further assessment of the presence of MDD (Radloff, 1977). High internal consistency reliability results (ranging from .85 to .92) have been found for the CES-D among various age, sex, geographic, and racial-ethnic subgroups. Validation studies have found that the CES-D has good convergent validity, discriminant validity (Himmelfarb, \& Murrell, 1983), and sensitivity and specificity (Mulrow et al., 1995). The Arabic version of the measure has been used previously on Iraqi refugees in Michigan, and found to have good reliability (alpha $=.92$ ), and predictive validity. It has alpha of .89 in the current study (e.g., Kira et al., 2011).

DASS-A General Anxiety DASS-A: Anxiety Measure (14 items): DASS is a 42-item scale developed by Lovibond and Lovibond, 1995, and includes three sub-scales that measure depression, anxiety, and stress. According to Antony, Bieling, Cox, Enns, and Swinson, 1998, DASS may hold more promise for distinguishing between anxiety and depression as well as between physical arousal and symptoms of generalized anxiety. DASS-A sub-scale measures anxiety, which is increasingly used in different clinical and research settings. Different studies suggest that DASS-A possess adequate convergent validity, with reliability of .84 in non-clinical samples and .89 , and 91 in clinical samples (e.g., Lovibond, \& Lovibond, 1995). Its authors reported alpha reliability of .89 in clinical sample. ). The Arabic version of the measure has been used previously on Iraqi refugees in Michigan, and found to have good reliability $($ alpha $=.89)$, and predictive validity. It has alpha of .86 in the current study.

CTD (Cumulative Trauma disorder) Cumulative Trauma Disorders Measure CTD: The 15-item measure was developed by Kira and associates in three studies on Iraqi refugees: Kira. (2004), Kira, Clifford, \& Al-haider, (2002), Kira, Clifford \& Al-Haider, (2003). It proved to have high reliability (ranged from .85 and .98), construct, and convergent, divergent and predictive validity. Test-retest reliability in a 6 week-interval is .76. Different kinds of traumas, torture, and severity of torture, number of divorces and remarriage, and cumulative trauma in general accounted for significant variance as predictors of CTD symptoms. Exploratory factor analysis found that the measure has four factors and four sub-scales: Executive function deficits, suicidality, dissociation, and depression/ anxiety interface. Confirmatory factor analysis confirmed this structure with comparative fit index of .99 . The suicidality subscale will be used especially to test some of our hypothesis.

\section{Analysis}

Multiple regressions was utilized to test predictors of suicidality, fear of death, militancy and annihilation anxiety controlling for age, gender, family size, and grades.

Different plausible path models were tested to explore the direct, and indirect effects of the independent variables using structural equation model SEM (AMOS 7 software), (Arbuckle, 2006). Model fit indices were selected in accordance with several recommendations and included the normed $\chi^{2}$ test statistic $\left(\chi^{2} / \mathrm{d} f\right)$, the root mean square error of approximation (RMSEA) and the comparative fit index (CFI). $\chi^{2} / \mathrm{d} f$ values $<5.0$ are considered acceptable; RMSEA values $\leq 0.05$ indicate close fit, values 0.05 to 0.08 indicate reasonable fit, and values $>0.10$ indicate poor fit . CFI values $>0.95$ indicate good fit (e.g., Kline, 2005; Hu, \& Bentler, 1999). We used bootstrap ( $=200)$ with bias-corrected confidence intervals to test the significance of the direct and indirect effects of each variable in the model. Bootstrapping is a computer-intensive re-sampling technique. It involves generating bootstrap samples based on the original observations. Bootstrapping is often used to get a better approximation of sampling distribution of a statistic than its theoretical distribution provides, especially when assumption of normality may be violated. Bootstrapping is more robust modern statistics that are used to generate and to create a sampling distribution, and this bootstrapped distribution is used to compute $p$ values, test hypotheses and generate confidence intervals for direct and indirect effects (e.g., Erceg-Hurn, \& Mirosevich, 2008).

\section{The Second Study: Results}

Hypothesis 1: Self-efficacy, autonomous functioning and agency is at the core of identity commitment and militancy;

Fear of death, attachment trauma (e.g., abandonment by mother) and achievement trauma (e.g., school failure) did not predict either of the collective identity salience variables, however, fear of loss of functioning (fear of loss of autonomy, and loss of efficacy and independence in old age) was the highest predictor of both $($ Beta $=.398$. for CIC, and CIM, beta $=.328)$. Self-efficacy, autonomous functioning and agency concerns seem to be at the core of identity commitment and militancy, which confirm one of identity theory theory's assumptions.

Hypothesis 2: Personal identity traumas predict identity commitment, while collective identity traumas predict increase in militancy.

Cumulative trauma dose, cumulative negative appraisal, personal identity traumas, Interdependence or secondary trauma and its negative appraisal, and annihilation anxiety predicted 
increase in identity commitment but not militancy. The Cumulative positive appraisal of traumas and collective identity traumas, family and survival traumas, PTSD, anxiety, and depression predicted increase in both identity commitment and militancy. However, positive appraisal of collective identity trauma, and of survival traumas, predicted militancy, but did not predict identity commitment (see Table 2).

Hypothesis 3 and 4: Predictors of Suicidality fear of death and Annihilation Anxiety

Fear of death with its two sub-scales was not significant predictor of suicidality. Annihilation anxiety was the strong predictor (beta $=.30$ ). Collective identity commitment was not significant predictor of suicidality, however, collective identity militancy (beta $=.11$ ) was. Cumulative trauma variables predicted suicidality (beta $=.27)$. Attachment traumas $($ beta $=.13)$, personal identity trauma (beta $=.18$ ), collective identity traumas $(.17)$, family traumas (beta $=.17$ ), survival traumas (beta $=$ 20 ), interdependence trauma (beta $=.25$ ), and cumulative stress trauma (beta $=.26$ ) all predicted suicidality.

Identity traumas, personal and collective predicted reduced fear of death, and increased annihilation anxiety (AA).

Hypothesis 5: Identity salience, annihilation anxiety (AA) (fear of identity annihilation), as well as fear of death mediates the effects of identity traumas on suicidality and militancy and mental health variables.

Using Path analysis we tested the model of identity salience in two conditions. The first condition was when the personal identity trauma is the independent variable in the model. The second condition was when the collective identity trauma is the independent variable in the model. In the first model, increased personal identity traumas predict direct increased in identity commitment (identity salience) and decrease in fear of death (mortality salience). Such traumas predict indirect increase in AA, depression and suicidality. Increased identity salience predicts directly an increase in AA and decrease in militancy. It predicts indirectly an increase in general anxiety, depression, PTSD, and suicidality. Increased $A A$ predicts, directly, increased mortality salience, and predicts both direct and indirect increase in militancy, general anxiety, depression and suicide. It predicts indirect increase in PTSD. Increased mortality salience

Table 2.

Multiple Regression of the effects of different variables on Identity Commitment and Militancy.

\begin{tabular}{|c|c|c|c|c|c|c|c|c|}
\hline \multirow[b]{2}{*}{ Dependent variables (a) } & \multicolumn{4}{|c|}{ Collective Identity Commitment } & \multicolumn{4}{|c|}{ Collective Identity Militancy } \\
\hline & B & SE & Beta & $\mathbf{P}$ & B & SE & Beta & $\mathbf{P}$ \\
\hline PTSD Scale & .063 & .020 & .164 & .002 & .049 & .014 & .185 & .000 \\
\hline CTD Scale & .079 & .033 & .127 & .016 & .032 & .023 & .074 & .164 \\
\hline CTD Depression/anxiety syndrome & .323 & .122 & .140 & .009 & .183 & .086 & .115 & .033 \\
\hline CTD Suicidality sub-scale (items 10,12 ) & .309 & .156 & .102 & .047 & .042 & .109 & .020 & .699 \\
\hline CTD Executive function deficits sub-scale & .517 & .163 & .164 & .002 & .248 & .114 & .115 & .031 \\
\hline CTD Dissociation/psychoses sub-scale & .271 & .118 & .118 & .023 & .026 & .083 & .017 & .754 \\
\hline Fear of death sub-scale & .344 & .357 & .052 & .335 & .170 & .249 & .037 & .495 \\
\hline Fear of loss of functioning (autonomy and efficacy) at old age b sub-scale & 2.644 & .329 & .398 & .000 & 1.493 & .236 & .328 & .000 \\
\hline DASS-Anxiety Scale & .137 & .059 & .121 & .020 & .099 & .041 & .127 & .016 \\
\hline Psychological anxiety-Sub-scale & .571 & .353 & .084 & .106 & .235 & .247 & .050 & .342 \\
\hline Physical anxiety sub-scale & .869 & .340 & .131 & .011 & .595 & .237 & .130 & .012 \\
\hline CES-D Depression Scale & .073 & .033 & .116 & .027 & .057 & .023 & .132 & .013 \\
\hline Annihilation anxiety scale & .351 & .126 & .142 & .006 & -.001 & .089 & -.001 & .989 \\
\hline Cumulative dose of trauma occurrence & .282 & .069 & .208 & .000 & .096 & .049 & .103 & .052 \\
\hline The negative appraisal of trauma dose & .131 & .055 & .123 & .016 & .066 & .038 & .089 & .086 \\
\hline The positive appraisal of trauma dose & .490 & .210 & .119 & .020 & .420 & .146 & .149 & .004 \\
\hline Attachment traumas occurrence sub-scale & 1.116 & .626 & .091 & .076 & .150 & .438 & .018 & .732 \\
\hline Personal identity trauma occurrence & .981 & .391 & .130 & .013 & .331 & .274 & .064 & .229 \\
\hline Negative appraisal of personal identity traumas & .598 & .297 & .103 & .044 & .134 & .208 & .034 & .520 \\
\hline Positive appraisal of personal identity traumas & 2.017 & .869 & .119 & .021 & 1.312 & .607 & .112 & .031 \\
\hline The frequency of collective identity traumatic events & .514 & .156 & .170 & .001 & .231 & .110 & .111 & .036 \\
\hline Negative appraisal of collective identity traumatic stressors & .575 & .213 & .141 & .007 & .343 & .149 & .122 & .022 \\
\hline Positive appraisal of collective identity traumatic events & 1.068 & .973 & .056 & .273 & 1.667 & .674 & .128 & .014 \\
\hline the occurrence of family traumatic stressors & 1.555 & .356 & .219 & .000 & .525 & .253 & .108 & .039 \\
\hline the occurrence of survival traumas & .635 & .177 & .188 & .000 & .281 & .124 & .121 & .025 \\
\hline The negative appraisal of survival traumatic stressors & .391 & .127 & .157 & .002 & .153 & .089 & .090 & .086 \\
\hline The positive appraisal of survival traumatic events & .674 & .468 & .074 & .150 & .644 & .325 & .103 & .048 \\
\hline Interdependence or secondary trauma occurrence & .630 & .183 & .175 & .001 & .205 & .129 & .083 & .112 \\
\hline The negative appraisal of secondary trauma events & .431 & .143 & .153 & .003 & .136 & .101 & .070 & .179 \\
\hline The positive appraisal of secondary traumas & .774 & .467 & .084 & .099 & .969 & .323 & .154 & .003 \\
\hline Achievement trauma occurrence (School failures) & 1.405 & 2.718 & .027 & .605 & -.562 & 1.895 & -.016 & .767 \\
\hline
\end{tabular}

(a) The results have been obtained after age, gender, education; income and family size have been controlled statistically. 
directly predicts increased militancy and general anxiety. It predicts direct and indirect increase in PTSD, and indirect increase in depression and suicidality. Increased militancy predicts direct decrease in depression, and indirect decrease in PTSD and suicidality. The model has good fit with Chi Square
$=22.546, \mathrm{df} .=15, \mathrm{p}=.094, \mathrm{CFI}=.989, \mathrm{RMSEA}=.034$. Figure 2 illustrates the model and Table 3 describes the decomposition of standardized direct, indirect and total effects of every independent variable in the model and its significance.

The second model, has adequate fit (Chi Square $=21.808$,

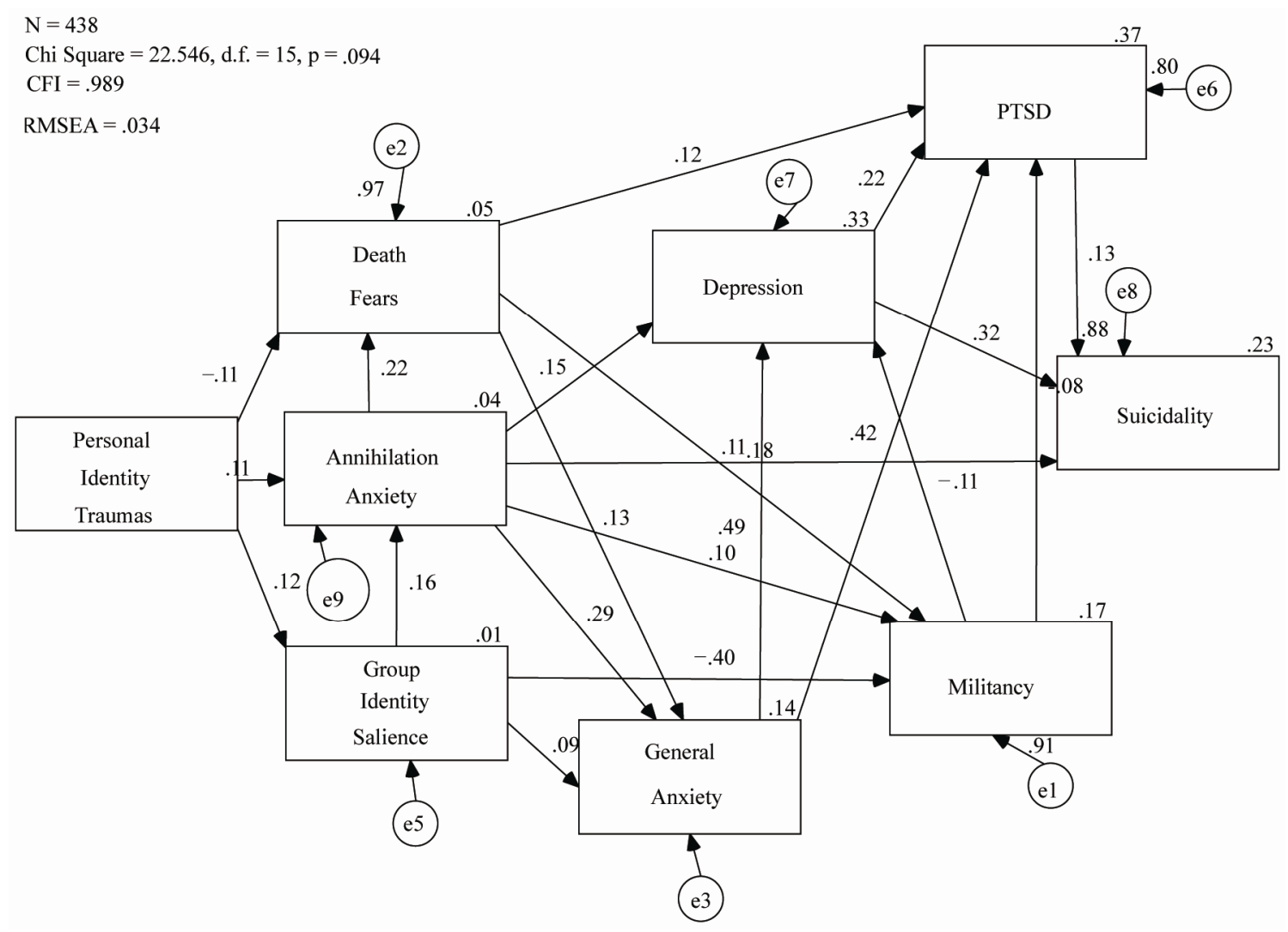

Figure 2.

Path model for the effects of personal identity trauma on suicidality and militancy.

Table 3.

Decomposition of standardized effects for a model of the effects of personal identity trauma on suicidality and militancy.

\begin{tabular}{|c|c|c|c|c|c|c|c|c|}
\hline \multirow{2}{*}{ Predictive Variables } & \multicolumn{8}{|c|}{ Endogenous Variables } \\
\hline & Collective Identity Commitment & AA & Death fear & Militancy & A & Depression & PTSD & Suicide \\
\hline \multicolumn{9}{|c|}{ Personal Identity Trauma (CIT) } \\
\hline Direct Effects & $.116^{*}$ & .108 & $-.114^{* *}$ & .000 & .000 & .000 & .000 & .000 \\
\hline Indirect Effects & .000 & $.019^{*}$ & $.028^{*}$ & $-.042+$ & $.037+$ & $.042^{* *}$ & .018 & $.038^{*}$ \\
\hline Total Effects & $.116^{*}$ & $.127^{*}$ & $-.086^{*}$ & $-.042+$ & $.037+$ & $.042^{* *}$ & .018 & $.038^{*}$ \\
\hline \multicolumn{9}{|c|}{ Identity Salience (Commitment) } \\
\hline Direct Effects & .000 & $.163^{* *}$ & .000 & $-.395^{*}$ & $.093+$ & .000 & .000 & .000 \\
\hline Indirect Effects & .000 & .000 & $.036^{* *}$ & $.036^{* *}$ & $.021^{* *}$ & $.138^{* *}$ & $.123^{* *}$ & $.088^{* *}$ \\
\hline Total Effects & .000 & $.163^{* *}$ & $.036^{* *}$ & $-.374^{* *}$ & $.145^{* *}$ & $.138^{* *}$ & $.123^{* *}$ & $.088^{* *}$ \\
\hline \multicolumn{9}{|c|}{ Annihilation Anxiety (AA) } \\
\hline Direct Effects & .000 & .000 & $.219^{* *}$ & $.103^{*}$ & $.293^{* *}$ & $.154^{* *}$ & .000 & $.176^{* *}$ \\
\hline Indirect Effects & .000 & .000 & .000 & $.023^{* *}$ & $.027^{*}$ & $.143^{* *}$ & $.214^{* *}$ & $.121^{* *}$ \\
\hline Total Effects & .000 & .000 & $.219^{* *}$ & $.127^{* *}$ & $.320^{* *}$ & $.297^{* *}$ & $.214^{* *}$ & $.297^{* *}$ \\
\hline \multicolumn{9}{|l|}{ Fear of Death } \\
\hline$\overline{\text { Direct Effects }}$ & .000 & .000 & .000 & $.107^{* *}$ & $.125^{*}$ & .000 & $.115^{*}$ & .000 \\
\hline Indirect Effects & .000 & .000 & .000 & .000 & .000 & $.049^{*}$ & $.055^{*}$ & $038^{*}$ \\
\hline Total Effects & .000 & .000 & .000 & $.107^{* *}$ & $.125^{*}$ & $.049^{*}$ & $.170^{*}$ & $.038^{* *}$ \\
\hline \multicolumn{9}{|l|}{ Militancy } \\
\hline Direct Effects & .000 & .000 & .000 & .000 & .000 & $-.112^{* *}$ & $-.076+$ & .000 \\
\hline Indirect Effects & .000 & .000 & .000 & .000 & .000 & .000 & $-.025^{* *}$ & $-.048^{* *}$ \\
\hline Total Effects & .000 & .000 & .000 & .000 & .000 & $-.112^{* *}$ & $-.101^{* *}$ & $-.048^{* *}$ \\
\hline Squared Multiple Correlations & .013 & .042 & .054 & .166 & .135 & .326 & .365 & .230 \\
\hline
\end{tabular}

$+p<.10$ (close top significance) ${ }^{*} p<.05 .{ }^{* *} p<.01$. 
df. $=16, p=.149, \mathrm{CFI}=.992, \mathrm{RMSEA}=.029)$, In the second model increased collective identity traumatic events predict, directly, increased identity commitment (identity salience) and increased AA, and predict, indirectly, increase in fear of death (mortality salience), general anxiety, depression, PTSD, and suicidality. Increased identity salience, in this model, directly predicts increased AA, and predicts, indirectly, increased mortality salience. It also predicts decrease in militancy, and indirectly, predict increase in general anxiety, depression, PTSD and suicidality. Increased $A A$ predicts direct increase in fear of death (mortality salience), and predict direct and indirect increase in militancy, general anxiety, depression and suicidality. It predicts, indirectly, PTSD. Increased fear of death (mortality salience) predicts direct increase in militancy and general anxiety. It predicts directly and indirectly PTSD. It predicts indirectly increased depression and suicidality. Increased militancy, as in the first model, predicts direct decrease in depression, and indirect decrease in PTSD and suicidality. Militancy plays an effective role as a coping mechanism to lower increased PTSD, depression and anxiety resulting from high traumatic events, personal and collective, as it predicts decrease in such symptoms.

In both path models, increased general anxiety predicts direct increase in depression and direct and indirect increase in PTSD, and indirect increase in suicidality. Increased depression predicts direct increase in PTSD, and direct and indirect increase in suicidality. Increased PTSD directly predicts suicidality.

Table 4 describes the decomposition of standardized direct, indirect and total effects of every variable and its significance in the model.

Alternative models: Care must be taken when making causal inferences from cross-sectional data. The theoretical argument for the proposed models is strong and the model fitted the data well; however, there are always alternative models (MacCallum, \& Austin, 2000). We considered several alternative models in which we changed the order of the, mediators, and eliminate identity salience and fear of death alternatively. In the alternative models (AM), with PIT as predictor we eliminate fear of death from the mediator variables, the model fit improved, when identity salience was removed, the model fit get worse, when we replaced interchangeably AA with PTSD, Depression and anxiety, as a mediating variables, the model fit get worse. In the alternative models with CIT as predictor, we eliminate fear of death from the mediator variables, the model fit stayed almost the same, when identity salience was removed, the model fit get worse, when we replaced interchangeably AA with PTSD, Depression and anxiety, as a mediating variables, the model fit get worse (see Table 5). The results highlighted the importance of adding identity salience as mediating variable to explain suicidality and militancy.

\section{Discussion}

The results generally indicate adequate reliability, construct and predictive validity for the identity salience measure and its two sub-scales that have been developed. The reliability of the other measures used was adequate in the current data. It seems that identity commitment and identity militancy represent related but unique concepts. Identity commitment is more relevant to personal identity salience, while identity militancy is another important identity dimension that is more relevant to group and political dynamics.

The findings generally suggest that identity salience, personal and collective, are important and can be strong explanatory variable that contribute to explaining the dynamics of identity and its development. Identity salience, personal and collective is another dimension of adolescent and adult development.

The results generally fit the predictions of TDT which gives the scale an adequate predictive validity. Identity traumas are strong causal variables in predicting identity fears, commitment and militancy. Identity trauma, personal and collective predicted increased identity commitment (identity salience), and increased suicidality. Personal identity trauma activated identity salience and deactivated mortality salience (decreased fear of death) increasing the suicidality and to some degree militancy. However, contrary to the TDT theory's predictions, AA did not decrease fear of death; it actually increased it in both models. Fear of identity loss increased fear of death. However, personal

Table 4.

Decomposition of standardized effects for the model of collective identity trauma on suicidality and militancy.

\begin{tabular}{|c|c|c|c|c|c|c|c|c|}
\hline \multirow{2}{*}{ Predictive Variables } & \multicolumn{8}{|c|}{ Endogenous Variables } \\
\hline & Identity Salience & AA & Death fear & Militancy & A & Depression & PTSD & Suicide \\
\hline \multicolumn{9}{|c|}{ Collective Identity Trauma (CIT) } \\
\hline Direct Effects & $.191^{* *}$ & $.352^{* *}$ & .000 & .000 & .000 & .000 & .000 & .000 \\
\hline Total Effects & $.191^{* *}$ & $.373^{* *}$ & $.076^{* *}$ & -.029 & $.136^{* *}$ & $.128^{* *}$ & $.096^{* *}$ & $.118^{* *}$ \\
\hline \multicolumn{9}{|c|}{ Identity Salience (Commitment) } \\
\hline Direct Effects & .000 & $.108^{*}$ & .000 & $-.395^{*}$ & $.093+$ & .000 & .000 & .000 \\
\hline Indirect Effects & .000 & .000 & $.022^{*}$ & $.014^{*}$ & $.034^{*}$ & $.122^{* *}$ & $.111^{* *}$ & $.072^{* *}$ \\
\hline Total Effects & .000 & $.108^{*}$ & $.022^{*}$ & $-.382^{*}$ & $.127^{*}$ & $.122^{* *}$ & $.111^{* *}$ & $.072^{* *}$ \\
\hline \multicolumn{9}{|c|}{ Annihilation Anxiety (AA) } \\
\hline Direct Effects & .000 & .000 & $.204^{* *}$ & $.104^{*}$ & $.293^{* *}$ & $.154^{* *}$ & .000 & $.176^{* *}$ \\
\hline Indirect Effects & .000 & .000 & .000 & $.022^{* *}$ & $.026^{*}$ & $.142^{* *}$ & $.212^{* *}$ & $.121^{* *}$ \\
\hline Total Effects & .000 & .000 & $.204^{* *}$ & $.125^{* *}$ & $.318^{* *}$ & $.296^{* *}$ & $.212^{* *}$ & $.297^{* *}$ \\
\hline \multicolumn{9}{|l|}{ Fear of Death } \\
\hline$\overline{\text { Direct Effects }}$ & .000 & .000 & .000 & $.107^{* *}$ & $.125^{*}$ & .000 & $.115^{*}$ & .000 \\
\hline Indirect Effects & .000 & .000 & .000 & .000 & .000 & $.049^{*}$ & $.055^{*}$ & $.038^{*}$ \\
\hline \multicolumn{9}{|l|}{ Militancy } \\
\hline Direct Effects & .000 & .000 & .000 & .000 & .000 & $-.112^{* *}$ & -.076 & .000 \\
\hline Indirect Effects & .000 & .000 & .000 & .000 & .000 & .000 & $-.025^{* *}$ & $-.048^{* *}$ \\
\hline Total Effects & .000 & .000 & .000 & .000 & .000 & $-.112^{* *}$ & $-.101^{* *}$ & $-.048^{* *}$ \\
\hline Squared Multiple Correlations & .036 & .150 & .042 & .166 & .135 & .326 & .365 & .230 \\
\hline
\end{tabular}


Table 5.

Alternative models (AM) for the effects on Personal Identity Traumas (PIT), and Collective Identity Traumas (CIT), on suicidality and militancy.

\begin{tabular}{|c|c|c|c|c|}
\hline & Predictor variable(s) & Mediating variables & Outcome variables & Model Fit \\
\hline AM1 & PIT & Identity salience and fear of death & $\begin{array}{l}\text { Suicidality, Militancy } \\
\text { PTSD, depression, anxiety }\end{array}$ & $\chi^{2}=22.546, \mathrm{df}=15, \mathrm{p}=.094, \mathrm{CFI}=.989, \mathrm{RMSEA}=.034$ (Chosen) \\
\hline AM2 & PIT & Identity, salience variables & $\begin{array}{l}\text { Suicidality, Militancy } \\
\text { PTSD, depression, anxiety }\end{array}$ & $\chi^{2}=16.547, \mathrm{df} .=12, \mathrm{p}=.167$, RMSEA $=.029($ BEST FIT $)$ \\
\hline AM3 & PIT & Fear of death & $\begin{array}{l}\text { Suicidality, Militancy } \\
\text { PTSD, depression, anxiety }\end{array}$ & $\chi^{2}=27.564, \mathrm{df}=7, \mathrm{p}=.000, \mathrm{CFI}=.957, \mathrm{RMSEA}=.082$ \\
\hline AM4 & PIT & $\begin{array}{l}\text { General anxiety } \\
\text { Fear of death }\end{array}$ & $\begin{array}{l}\text { Suicidality, Militancy } \\
\text { PTSD, depression, AA }\end{array}$ & $\chi^{2}=107.147$, df. $=15, p=.000 .$, CFI $=.861$, RMSEA $=.119$ \\
\hline AM5 & PIT & $\begin{array}{l}\text { PTSD } \\
\text { Fear of death }\end{array}$ & $\begin{array}{l}\text { Suicidality, Militancy } \\
\text { AA depression, Anxiety }\end{array}$ & $\chi^{2}=30.777$, df. $=15, \mathrm{p}=.009, \mathrm{CFI}=.976, \mathrm{RMSEA}=.049$ \\
\hline AM6 & PIT & $\begin{array}{l}\text { Depression } \\
\text { Fear of death }\end{array}$ & $\begin{array}{l}\text { Suicidality, Militancy } \\
\text { PTSD, AA }\end{array}$ & $\chi^{2}=61.795, \mathrm{df} .=15, \mathrm{p}=.000, \mathrm{CFI}=.930, \mathrm{RMSEA}=.084$ \\
\hline AM1 & CIT & Identity salience and fear of death & $\begin{array}{l}\text { Suicidality, Militancy } \\
\text { PTSD, depression, anxiety }\end{array}$ & $\chi^{2}=21.808, \mathrm{df} .=16, \mathrm{p}=.149, \mathrm{CFI}=.992, \mathrm{RMSEA}=.029$ (Chosen) \\
\hline AM2 & CIT & Identity salience variables & $\begin{array}{l}\text { Suicidality, Militancy } \\
\text { PTSD, depression, anxiety }\end{array}$ & $\chi^{2}=18.972$, df. $=12, \mathrm{p}=.089, \mathrm{CFI}=.990$, RMSEA $=.036$ \\
\hline AM3 & CIT & Fear of death & $\begin{array}{l}\text { Suicidality, Militancy } \\
\text { PTSD, depression, anxiety }\end{array}$ & $\chi^{2}=14.949, \mathrm{df}=6, \mathrm{p}=.021, \mathrm{CFI}=.981, \mathrm{RMSEA}=.058$ \\
\hline AM4 & CIT & $\begin{array}{l}\text { General anxiety } \\
\text { Fear of death }\end{array}$ & $\begin{array}{l}\text { Suicidality, Militancy } \\
\text { PTSD, depression, AA }\end{array}$ & $\chi^{2}=153.402, \mathrm{df} .=16, \mathrm{p}=.000, \mathrm{CFI}=.809, \mathrm{RMSEA}=.140$ \\
\hline AM5 & CIT & $\begin{array}{l}\text { PTSD } \\
\text { Fear of death }\end{array}$ & $\begin{array}{l}\text { Suicidality, Militancy } \\
\text { AA depression, Anxiety }\end{array}$ & $\chi^{2}=85.737, \mathrm{df} .=16, \mathrm{p}=.000, \mathrm{CFI}=.903, \mathrm{RMSEA}=.100$ \\
\hline AM6 & CIT & $\begin{array}{l}\text { Depression } \\
\text { Fear of death }\end{array}$ & $\begin{array}{l}\text { Suicidality, Militancy } \\
\text { PTSD, AA }\end{array}$ & $\chi^{2}=119.380$, df. $=16, p=.000$, CFI $=.856$, RMSEA $=.122$ \\
\hline
\end{tabular}

identity trauma directly reduced fear of death. Further, as the theory anticipated, AA (fear of identity loss) predicted directly an increase in militancy and suicidality, while fear of death indirectly predicted suicidality, but not militancy.

Clinical suicidality is separate syndrome different from readiness to die for the group (militancy) and is more present in the case of personal identity trauma. Suicidality is mediated by AA (fear of identity loss) and associated with depression, anxiety and PTSD.

One of the important findings is that increased militancy, in both models, predicted direct decrease in depression, and indirect decrease in PTSD and suicidality. Militancy seems to play a positive role as a coping mechanism to lower increased $P T S D$, depression and anxiety resulting from high personal and collective identity trauma load. In other words, militancy plays as a buffer against increase in AA, in fear of death and associated mental health syndromes. Militancy, ready to die for the group, seems to be opposite to clinical suicidality. Another important finding is that while both AA (fear of identity loss) and fear of death predicted increased militancy, identity commitment predicted decreased militancy. Identity commitment, in political conflicts, may act as positive factor after all.

Another important findings is that fear of loss of functioning, (fear of loss of independence and loss of self-efficacy, i.e., due to age) was the strongest predictor of identity salience, confirming, at least partly, the assumption that self-efficacy and agency, that have been acquired through the individuation developmental processes, buffers against fear of identity loss. Fear of identity loss (annihilation anxiety) predicted identity commitment, and decreased militancy

Why people, who usually fear death and strive to live, commit suicide or sacrifice their lives for their groups? Our findings derived from developmental theories, provide some answers and more questions. Alternative theories, other than TDT, provide different explanations and hypotheses. One of the other strong theories proposed to explain the terror originated in the core of the existential condition of the individual's inherent death threats, is Terror Management Theory (TMT). According to (TMT) (e.g., Becker, 1962, 1973; Pyszczynski, Greenberg, \& Solomon, 1999), a great deal of human behavior can be understood as attempts to gain psychological equanimity in the face of awareness of inevitability of death. In recent development of the theory (e.g., Kruglanski, Chen, Dechesne, Fishman, \& Orneck, 2009), TMT added that humans struggle for a sense of identity and significance in the world, (partly), as a way to protect themselves against death and its anxieties. This search for validation and value, sometimes, takes the form of expanding oneself in a larger beyond, such as one's group or nation. These serve as avenues for the person to find meaning and value in a vaster scheme that will not be shattered by one's own death. As such, the pursuit of symbolic immortality can assuage fear of death. Mortality reminders, under certain conditions, found to make participants express greater willingness to sacrifice their selves for their country (Routledge, \& Arndt, 2008).

Navarrete, Kurzban, Fessler, and Kirkpatrick, 2004, provide different evolutionary-based argument as well as experimental evidence that question the primacy of mortality salience causality hypotheses. Marshaling social support was a reliably adaptive need to deal with adversities in human evolutionary path by forming social network and coalitions to improve group survival potential. In-group affliliative sentiments are necessary to obtain needed social support and can have strong explanatory power for the same behaviors that are believed to be due to mortality reminders (see also, Kirkpatrick, \& Navarrete, 2006).

While developmentally based TDT assumptions, as well as evolutionary-based coalition psychology assumptions can be reconciled theoretically within the robust TMT framework, the primacy of identity salience contrasted with the primacy of mortality salience, or the primacy of affliliative sentiments salience, should be resolved in subsequent controlled or longi- 
tudinal studies.

\section{Implications of the Results}

While the results have theoretical implications for individuation and identity development in social and political context, we need to brainstorm and utilize the current findings to develop different ways to reduce suffering in ways other than becoming a militant with increased violence and terrorist suicide, or committing clinical suicide. The finding about the role of militancy in alleviating mental health suffering in those traumatized adolescents is important. Providing effective multi-systemic and ecological interventions and supports to children, adolescents and adults, in addition to conflict resolution and reconciliation efforts, may reduce militancy as well as clinical suicide. Further, the finding that identity commitment actually reduces militancy is equally important. Interventions that enhance positive identity development in youth should prevent increased militancy and suicidality. Identity commitment, in itself can be positive indicator; fear of identity loss due to different events can be alleviated by focusing on positive identity development for those affected. Reducing collective traumatic events and preventing its cross-generational transmission can reduce suffering and enhance future peace and conflict resolution. Devising interventions that interrupt and stop the cycle of cross-generational transmission of such intractable collective identity traumas is another important task. Such brainstorming can yield some successful strategies to alleviate pain and suffering of the groups. Current study can be a one step toward such scientific analysis that can set progress toward peace and identity conflict resolution and reduce or eliminate terror.

\section{Limitations}

This pilot study has its definite limitations. The current cross-sectional study does not explicitly draw causality from the results. We realize the limitation of causal analysis with SEM (e.g., Bullock, Harlow, \& Mulaik, 1994; Rosenbaum, 2002). Unobserved confounding variables can distort statistical causal inference. These may be impossible to eliminate their effects in observational studies. However, there are cases where only observational data are available and one cannot conduct any experimental studies. Experimental studies, e.g., using death reminders, may not simulate the real effects of actual personal and collective identity traumas for such populations. For these cases, SEM is powerful tools for causal statistical causal inference, although one has to pay very careful attention to confounding variables. One caution should be made here. We must not assert that causation is established based solely on the results derived from SEM but should make substantive arguments as well.

Future replications on different populations and longitudinal studies could reach such inference of causality. Nevertheless, the findings of our study provide preliminary evidence of the important associations between identity variables and increased or reduced distress and symptom clusters of PTSD, depression, anxiety, suicidality and militancy.

\section{References}

Antony, M. M., Bieling, P. J., Cox, B. J., Enns, M. W., \& Swinson, R. P. (1998). Psychometric properties of the 42 -item and 21-item versions of the Depression Anxiety Stress Scales in clinical groups and a community sample. Psychological Assessment, 10, 176-181. doi: $10.1037 / 1040-3590.10 .2 .176$

Arbuckle, J. L. (2006). Amos 7.0 User's Guide. Chicago: SPSS.
Ashmore, R. D., Deaux, K., \& McLaughlin-Volpe, T. (2004). An organizing framework for collective identity: Articulation and significance of multidimensionality. Psychological Bulletin, 130, 80-114. doi:10.1037/0033-2909.130.1.80

Bandura, A. (1997), Self-efficacy: The exercise of control, New York: Freeman.

Becker, E. (1962). The birth and death of meaning. New York: Free Press.

Becker, E. (1973). The denial of death. New York: Free Press.

Bowlby, J. (1969). Attachment and loss. Vol. 1: Attachment. New York: Basic Books.

Bowlby, J. (1988). A secure base (2nd ed.). New York: Basic Books.

Blake, D. D., Weathers, F. W., Nagy, L. M., Kaloupek, D. G., Klauminzer, G., Charney, D. S., \& Keane, T. M. (1990). A clinician rating scale for assessing current and lifetime PTSD: The CAPS-1. The Behavior Therapist, 13, 187-188.

Bullock, H. E., Harlow, L.L., Mulaik, S. A., (1994). Causal issues in structural equation modeling research. Structural Equation Modeling, 1,253-267. doi:10.1080/10705519409539977

Carmel, S. \& Mutran, E. (1997a). Wishes regarding the use of lifesustaining treatments among elderly persons in Israel: An explanatory model. Social Science and Medicine, 45, 1715-1727. doi:10.1016/S0277-9536(97)00104-4

Carmel, S., \& Mutran, E. (1997b). Preferences for different life-sustaining treatments among elderly persons in Israel. Journal of Gerontology, 52B, S97-S102. doi:10.1093/geronb/52B.2.S97

Cassiman, S. A. (2005). Toward more inclusive poverty knowledge: Traumatological contributions to the poverty discourse. The Social Policy Journal, and: Cutting Edge of Social Policy Research, 4, 93106.

Erceg-Hurn, D. \& Mirosevich, V. (2008). Modern robust statistical methods: An easy way to maximize the accuracy and power of your research. American Psychologist, 63, 591-601. doi:10.1037/0003-066X.63.7.591

Erikson, E. H. (1963). Childhood and society (2nd ed.). New York: Norton.

Erikson, E. H. (1980). Identity and the life cycle. (2nd ed.). New York: Norton.

Gross, F. L. (1987). Introducing Erik Erikson: An invitation to his thinking. Lanham, MD: University Press of America.

Hu, L., Bentler, \& P. M. (1999). Cutoff criteria for fit indexes in covariance structure analysis: conventional versus new alternatives. Structural Equation Modeling, 6, 1-55. doi:10.1080/10705519909540118

Ibn Khaldûn. (1968). Al-Muqaddima (Discours sur l'histoire universelle), Tome 1. Paris: Sindbad. (Original work published 1377).

Kira, I. (2010). Etiology and Treatments of post-cumulative traumatic Stress disorders in Different Cultures. Traumatology: An International Journal, 16, 128-141.

Kira, I. (2006). Collective identity terror in the Israeli-Palestinian conflict and potential solutions. In J. Kuriansky (Ed.), Terror in the Holy land, inside the anguish of Israeli-Palestinian Conflict (pp. 125-130). New York: Praeger.

Kira, I. (2002, August). Suicide terror and collective trauma: A collective terror management paradigm. Chicago, Illinois: American Psychological Association Annual Convention.

Kira, I. (2004). Cumulative Trauma Disorder: A new scale for complex PTSD. Proceeding of the XXVIII International Congress of Psychology, Beijing.

Kira, I. (2001). Taxonomy of trauma and trauma assessment. Traumatology, 2, 1-14.

Kira, I. (1997). Value Processing: A clinical cross-cultural model (an empirical study). Ph.D. Dissertation, Columbia: Columbia University.

Kira, I. (1987). Human values: A conceptual model for the dynamics of value processing. Master Thesis, Hayward: California State University.

Kira, I., Templin, T., Lewandowski, L., Ramaswamy, V., Bulent, O., Abu-Mediane, S., Mohanesh, J., \& Alamia, H. (2011). Cumulative Tertiary appraisal of traumatic events across cultures: Two studies. Journal of Loss and Trauma: International Perspectives on Stress \& Coping, 16, 43-66.

Kira, I., Lewandowski, L., Templin, T., Ramaswamy, V., Ozkan, B., \& 
Mohanesh, J. (2008). Measuring cumulative trauma dose, types and profiles using a development-based taxonomy of trauma, Traumatology, 14, 62-87. doi:10.1177/1534765608319324

Kira, I., Clifford, D. \& Al-haider (2003). Assessing and treating cumulative trauma disorders (CTD) in Iraqi refugees. In American Psychological Association Annual Convention, Toronto.

Kira, I., Clifford, D., \& Al-Haidar, A. (2002). Cumulative Trauma Disorder in Iraqi refugees in Michigan: A Preliminary data. In Second Annual Symposium on Refugee, Dearborn, Michigan.

Kirkpatrick, L. A., \& Navarrete, C. D. (2006). Reports of my death anxiety have been greatly exaggerated: A critique of terror management theory from an evolutionary perspective. Psychological Inquiry, 17, 288-298. doi:10.1080/10478400701366969

Kline R. B. (2005). Principles and practice of structural equation modeling (2nd ed.). New York: The Guilford Press.

Kruglanski, A. W., Chen, X.,Dechesne, M., Fishman, S., \& Orehek, E. (2009). Fully Committed Suicide bombers' motivations and the quest for personal significance. Political Psychology, 30, 331-357. doi:10.1111/j.1467-9221.2009.00698.x

Lovibond, P. F., \& Lovibond, S. H. (1995). The structure of negative emotional states: Comparison of the Depression Anxiety and Stress Scales (DASS) with the Beck Depression and Anxiety Inventories, Behavior Research and Therapy, 33, 335-342. doi:10.1016/0005-7967(94)00075-U

McCall, G. J., \& Simmons, J. L. (1978). Identities and interactions (Rev. ed.). New York, NY: Free Press.

Mulrow C., Williams J. W., Gerety, M. B., Ramirez, G., Montiel, O. M., \& Kerber, C. L.: Case-finding instruments for depression in primary care settings. Annals of Internal Medicine, 122, 913-921.

Orme, J. G.; Reis, J, \& Herz, E. J. (1986). Factorial and discriminant validity of the Center for Epidemiological Studies Depression (CESD) scale. Journal of Clinical-Psychology, 42, 28-33. doi:10.1002/1097-4679(198601)42:1<28::AID-JCLP2270420104>3. $0 . \mathrm{CO} ; 2-\mathrm{T}$

MacCallum, R. C., \& Austin, J. T. (2000). Applications of structural equation modeling in psychological research. Annual Review of Psychology, 51, 201-226. doi:10.1146/annurev.psych.51.1.201

McGregor, H. A., Lieberman, J. D., Greenberg, J., Solomon, S., Aradt, J., Simon, L,. \& Pyszczynski, T. (1998). Terror management and aggression: Evidence that mortality salience motivates aggression against worldview-threatening others. Journal of Personality and Social Psychology, 74, 590-605. doi:10.1037/0022-3514.74.3.590

Pyszczynski, T., Greenberg, J., \& Solomon, S. (1999). A dual-process model of defense against conscious and unconscious death-related thoughts: An extension of terror management theory. Psychological
Review, 106, 835-845. doi:10.1037/0033-295X.106.4.835

Navarrete, C. D., Kurzban, R.; Fessler, D. \& Kirkpatrick, L. (2004). Anxiety and Intergroup Bias: Terror Management or Coalitional Psychology? Group Processes Intergroup Relations, 7, 370-397. doi: $10.1177 / 1368430204046144$

Radloff, L. S. (1977). The CES-D scale: A self-report depression scale for research in the general population, Applied Psychological Measurement, 1, 385-401. doi:10.1177/014662167700100306

Rasmussen, J., \& Erikson, E. E. (1963). Childhood and society (2nd ed.). New York: Norton.

Rosenbaum, P. R., (2002) Observational Studies (2nd ed.). New York: Springer.

Routledge, C., \& Arndt, J. (2008). Self-sacrifice as self-defense: Mortality salience increases efforts to affirm a symbolic immortal self at the expense of the physical self. European Journal of Social Psychology, 38, 531-541. doi:10.1002/ejsp.442

Smith, H. J., Spears, R., \& Hamstra, I. J. (1999). Social identity and the context of relative deprivation. In N. Ellemers, \& R. Spears (Eds.), Social identity: Context, commitment, content (pp. 205-229). Oxford, England: Basil Blackwell.

Stryker, S., \& Burke, P. J. (2000). The past, present, and future of an identity theory. Social Psychology Quarterly, 63, 284-297. doi: $10.2307 / 2695840$

Stryker, S., \& Serpe, R. T. (1982). Commitment, identity salience, and role behavior: A theory and research example. In W. Ickes, \& E. S. Knowles (Eds.), Personality, roles, and social behavior (pp. 199218). New York: Springer-Verlag.

Tajfel, H., \& Turner, J. C. (1986). The social identity theory of intergroup behavior. In S. Worchen \& W. G. Austin (Eds.), Psychology of intergroup relations (pp. 7-24). Chicago: Nelson Hall.

Templin, T., Kira, A., Lewandowski, L., Hammad, A., Mohanesh, J., \& Abdulkhaleq, H. (2006). Annihilation Anxiety, trauma dose, and trauma negative appraisal: A new measure for annihilation anxiety. In American Psychological Association Annual Convention, New Orleans, Louisiana.

Walker, I., \& Pettigrew, T. F. (1984). Relative deprivation theory: An overview and conceptual critique. British Journal of Social Psychology, 23, 301-310. doi:10.1111/j.2044-8309.1984.tb00645.x

Weathers, F., Keane, T., \& Davidson, J. (2001). The Clinician-Administered PTSD scale: A review of the first ten years of research. Depression and Anxiety. 13, 132-156. doi:10.1002/da.1029

Werner, P., \& Carmel, S. (2001b). Life-sustaining treatment decisions: Health care social workers' attitudes and their correlates. Journal of Gerontological Social Work, 34, 83-97. doi:10.1300/J083v34n04_07 